\title{
ІНФОРМАТИВНЕ ЗНАЧЕННЯ ІНДЕКСУ КЕРДО ДЛЯ ВИЗНАЧЕННЯ РІВНЯ ПОРУШЕНЬ ВЕГЕТАТИВНОЇ РЕГУЛЯЦІЇ ПРИ ОСТЕХОНДРОЗІ ШИЙНОГО ВІДДІЛУ ХРЕБТА
}

\author{
В. П. Марценюк, Д. В. Вакуленко, Л. О. Вакуленко \\ ДВНЗ „Тернопільський державний медичний університет імені І. Я. Горбачевського”
}

\begin{abstract}
В работе оценено информативное значение индекса Кердо у больных с нарушениями вегетативной регуляции при остеохондрозе шейного отдела позвоночника. Количество информации в следующих показателях: содержание адреналина и норадреналина в моче, активность ацетилхолинэстеразы в капиллярной крови, систолическое, диастолическое давление и частота сердечных сокращений у больных с неврологическими синдромами остеохондроза шейного отдела позвоночника оказались большими, чем значение количества информации в индексе Кердо при соответствующих патологии. Нам не удалось выявить достаточную информативность индекса Кердо для определения уровня и направленности нарушений вегетативной регуляции у больных с неврологическими синдромами остеохондроза шейного отдела позвоночника.
\end{abstract}

Остеохондроз хребта - найпоширеніше хронічне захворювання людства. Особливо багатий неврологічною симптоматикою остеохондроз шийного відділу хребта (ОШВХ). За даними світової літератури, його частка сягає 31-34 \%. 3 віком кількість хворих $з$ даною патологією зростає та стає максимальною в 45 64 роки [1]. Обов'язковою ланкою ланцюга патогенезу ОШВХ є вегетативні порушення $[1,2,3]$. Діагностика вегетативних вертеброгенних порушень $\epsilon$ важливим завданням, оскільки від їх характеру та тяжкості проявів залежить перебіг основного захворювання та ефективність лікування.

Наукові дослідження Я. Ю. Попелянського [3], М. К. Бротмана, Г. С. Юмашева, М. С. Фурмана [4, 5] показали, що в центрі вегетативних синдромів при шийному остеохондрозі знаходиться іритативний стан симпатичної ланки вегетативної нервової системи. Спектральний аналіз варіабельності серцевого ритму у хворих з неврологічними синдромами ОШВХ дав можливість ряду авторів $[6,7]$ підтвердити переважний вплив симпатичного відділу ВНС на їх серцевий ритм. Активація симпатичного відділу ВНС $\epsilon$ відображенням зниження адаптаційно-пристосувальних можливостей організму та причиною виникнення рефлекторних (судинних, трофічних, м'язовотонічних) змін у хворих на ОШВХ $[3,4,5]$.

Індекс Кердо застосовують для оцінки вегетативного тонусу, який вираховується на основі окремо взятих показників, що інтегрують практично всі життєві функції організму, а саме - кровообігу. Метод базується на клінічних спостереженнях Kerdo [8], які дали можливість прийти до висновку, що діастолічний тиск і число ударів серця за хвилину у стані вегетативної рівноваги приблизно рівні, а їх зміни пов' язані із зміною вегетативного тонусу. Відхилення показників індексу від нульового значення в бік його (c) В. П. Марценюк, Д. В. Вакуленко, Л. О. Вакуленко позитивних значень свідчить про підвищення тонусу симпатичної ланки вегетативної нервової системи, у бік негативних - парасимпатичної.

Метою нашого дослідження стало вивчення можливості використання простого та доступного індексу Кердо для визначення вегетативного тонусу у хворих з веретеброгенними синдромами ОШВХ. У літературних джерелах вдалось знайти окремі роботи, присвячені даному питанню. Одні автори (В. В. Поворознюк, Т. В. Орлик [9] ) указують, що за показниками індексу Кердо при вертебральному больовому синдромі до лікування у хворих переважає парасимпатичний тонус вегетативної нервової системи. В той же час, О. Юрик [10] відмічає, що у перші 3-4 дні загострення захворювання домінують симпатикотонічні прояви вегетативних реакцій. Особливо чітко ці ознаки проявлялися у осіб з неврологічними проявами остеохондрозу хребта на шийному рівні, на що вказували показники індексу Кердо. В процесі лікування вони швидко змінюються на парасимпатикотонічні”. Дослідження, проведені Г. І. Сиротинською [7], дали можливість автору прийти до висновку, що традиційні вегетативні показники (індекс Кердо та хвилинний об'єм крові) виявилися недостатньо інформативними для визначення рівня та спрямованості порушень вегетативної регуляції при ОШВХ.

Матеріал і методи дослідження. Нами обстежено 78 хворих 3 неврологічними синдромами ОШВХ віком 45-65 років в період загострення захворювання (основна група). У 40 з них був установлений компресійно-рефлекторний синдром хребтової артерії, у 10 - нейродистрофічний синдром, у $28-$ компресійно-корінцевий. Давність захворювання 5 15 років. В контрольну групу було включено 20 практично здорових осіб того ж віку.

Для визначення індексу Кердо вивчали частоту 
серцевих скорочень (ЧСС) та артеріальний тиск (діастолічний, АТд). Стан вегетативної нервової системи оцінювали за результатами біохімічних досліджень (вміст адреналіну і норадреналіну в добовій сечі (А. М. Бару, 1962) та активністю ацетилхолінестерази в капілярній крові (колориметричний метод Hestrin, 1949, в модифікації Сйдельмана, 1963).

Результати досліджень та їх обговорення. $B e$ гетативний індекс Кердо. Середні показники діастолічного артеріального тиску виявились вищими від частоти серцевих скорочень. Індекс Кердо при усіх неврологічних синдромах має від'ємне значення, що свідчить про перевагу функціонального стану парасимпатичної ланки вегетативної нервової системи. Найбільші негативні значення були притаманні хворим 3 компресійно-рефлекторним синдромом хребтової артерії, найменші-з нейродистрофічним.

Кількість інформації у значеннях індексу Кердо є найменшою, порівняно зі значеннями діастолічного тиску та частоти серцевих скорочень.

Біохімічні дослідження. Були вивчені активності адренергічних процесів у хворих. Можна зробити висновки, що обстеженим хворим з неврологічними синдромами ОШВХ притаманне значне підвищення вмісту адреналіну (на 126 \%) та в меншій мірі- норадреналіну (на 46,1 \%) в сечі. Дещо більшими були показники у хворих $з$ нейродистрофічним синдромом. Виявлені зміни вказують на активацію гормональної ланки симпатоадреналової системи.

Кількість інформації у показниках адреналіну та норадреналіну є більшою для відповідної патології, порівняно 3 кількістю інформації, що міститься у Індексі Кердо.

Отримані результати збігаються 3 даними досліджень Кердо [8], який після ін'єкцій адреналіну у обстежуваних реєстрував зниження АТд та зростання

\section{Лiтература}

1. Минцер О. П. Медицинские информационные системы: пути развития и перспективы в реальной жизни / О. П. Минцер // Кибернетика и вычислительная техника. 2001.-№ 2.-C. 37-60.

2. Marzeniuk V. P. System analysis methods of medical and biological processes / Marzeniuk V. P., Nakonechny A. G. Ternopil : Ukrmedknyha, 2003. - 241 p.

3. Попелянский Я. Ю. Ортопедичесая неврология (вертебрология): руководство для врачей / Я. Ю. Попелянский. / М. : МЕДпресс-информ, 2003.-244 с.

4. Вегетативные расстройства ; под ред. А. М. Вейна. М. : Медицинское информационное агентство, 2003. - 752 с. 5. Юмашев Г. С. Остеохондрзы позвоночника. - 2-е изд. / Юмашев Г. С., Фурман М. Г.-М. : Медицина, 1984-384 с.
ЧСС, що приводило до зміщення вегетативного індексу в бік позитивних значень. Аналогічні дані відносно співвідношення АТд та ЧСС на фоні впливу адреналіну чи інших симпатичних впливів знайдені і рядом інших авторів (Moller, 1947, Curry, 1949, Hofmeister, 1949) [7].

Кількість інформації у показнику активності ацетилхолінестерази крові у хворих на остеохондроз шийного відділу хребта залежно від неврологічних синдромів є більшою для відповідної патології, порівняно з кількістю інформації, що міститься у показниках Індексу Кердо.

Висновки. Від'ємні показники вегетативного індексу Кердо дають можливість прийти до висновку, що у хворих з неврологічними синдромами остеохондрозу шийного відділу хребта переважає тонус парасимпатичної ланки вегетативної нервової системи.

Вивчення вмісту адреналіну і норадреналіну в добовій сечі та активності ацетилхолінестерази в капілярній крові. Ці дані збігаються з результатами спектрального аналізу варіабельності серцевого ритму у хворих з неврологічними синдромами остеохондрозу шийного відділу хребта, проведеними Г.І. Сиротинською та іншими дослідниками [7]. Підтвердити отримані результати за допомогою індексу Кердо нам не вдалося.

Розраховані значення кількості інформації у наступних показниках: вміст адреналіну і норадреналіну в добовій сечі, активність ацетилхолінестерази в капілярній крові, систолічний, діастолічний тиск та частота серцевих скорочень у хворих з неврологічними синдромами остеохондрозу шийного відділу хребта. Вони виявились більшими, ніж значення кількості інформації у індексі Кердо при відповідних патологіях. Вважаємо, що індекс Кердо виявився недостатньо інформативним для визначення рівня та спрямованості порушень вегетативної регуляції у хворих з неврологічними синдромами остеохондрозу шийного відділу хребта.

6. Баевский Р. М. Вариабельность сердечного ритма: теоретические аспекты и возможности клинического применения / Р. М. Баевский, Г. Г. Иванов // Ультразвуковая и функциональная диагностика. -2001.-№ 3. - С. 106-127. 7. Сиротинська Г. І. Вегетативні порушення у хворих з нейрорефлекторними проявами остеохондрозу хребта / Г. І. Сиротинська//Проблеми остеології.-1998.-№2-3.-С. 122-126. 8. Kerdo I. Ein aus Daten der Blutzirkulation kalkulierter Index zur Beurteilung der vegetativen Tonuslage // Acta neurovegetativa, 1989, Bd.29. - № 2. - P. 250-268.

9. Поворознюк В. В., Орлик Т. В. в кн. : Сучасні принципи діагностики, профілактика та лікування захворювань кістково-м'язової системи в людей різного віку ; за ред. В. В. Поворознюка - К. : Карбон-сервіс, 2008. -С. 148-151. 